\title{
Toxoplasma-IgM AND IgG-AVIDITY IN SINGLE SAMPLES FROM AREAS WITH A HIGH INFECTION RATE CAN DETERMINE THE RISK OF MOTHER-TO-CHILD TRANSMISSION
}

\author{
Myrian Morussi REIS(1,2,3), Maria Madalena TESSARO(1) \& Pedro Alves D’AZEVEDO(2)
}

\begin{abstract}
SUMMARY
Anti-Toxoplasma IgG-avidity was determined in 168 serum samples from IgG- and IgM-positive pregnant women at various times during pregnancy, in order to evaluate the predictive value for risk of mother-to-child transmission in a single sample, taking the limitations of conventional serology into account. The neonatal $\operatorname{IgM}$ was considered the serologic marker of transmission. Fluorometric tests for IgG, IgM (immunocapture) and IgG-avidity were performed. Fifty-one of the 128 pregnant women tested gave birth in the hospital and neonatal IgM was obtained. The results showed $32(62.75 \%)$ pregnant women having high avidity, $\operatorname{IgM}$ indexes between 0.6 and 2.4, and no infected newborn. Nineteen (37.25\%) had low or inconclusive avidity, IgM indexes between 0.6 and 11.9, and five infected newborns and one stillbirth. In two infected newborns and the stillbirth maternal IgM indexes were low and in one infected newborn the only maternal parameter that suggested fetal risk was IgG-avidity. In the present study, IgG-avidity performed in single samples from positive IgM pregnant women helped to determine the risk of transmission at any time during pregnancy, especially when the indexes of the two tests were analysed with respect to gestational age. This model may be less expensive in developing countries where there is a high prevalence of infection than the follow-up of susceptible mothers until childbirth with monthly serology, and it creates a new perspective for the diagnosis of congenital toxoplasmosis.
\end{abstract}

KEYWORDS: Congenital toxoplasmosis; Serology for toxoplasmosis; IgG-avidity.

\section{INTRODUCTION}

The risk of mother-to-child transmission of Toxoplasma gondii and the severity of sequelae in congenital infection have been correlated with gestational age in which maternal seroconversion occurs ${ }^{4}$. Significant reduction in the frequency and severity of disease at birth have been associated with in utero treatment of infected fetuses ${ }^{1,16}$, even though treatment does not prevent transmission of the parasite ${ }^{24}$. The high prevalence of Toxoplasma infection in pregnant women from Porto Alegre has led to the use of serological screening in the local health care system ${ }^{12}$.

IgM antibodies may appear earlier and decline more rapidly than IgG antibodies and are frequently the first class of antibodies detected after primary infection ${ }^{17}$. Despite the wide distribution of commercial kits to measure IgM antibodies, they lack standardization; therefore, quantitative results from different manufacturers cannot be compared. Several methods for IgM detection still have a high frequency of falsepositives and in some patients, positive IgM is "residual", detected during the chronic phase of infection. A positive IgM result in an isolated sample can be interpreted as a true-positive in acute infection, a true-positive in chronic infection or as a false-positive ${ }^{17}$.
The IgM indexes measured in acute infection are significantly higher than those in residual ones ${ }^{25}$. With ELFA- enzyme-linked fluorescent assay, VIDAS system, increasing IgM indexes or over 3.5 were observed in acute infection, indexes between 3.0 and 3.5 in the transitional phase, and indexes between 0.65 and 3.0 in latent infection ${ }^{2}$.

An IgM test should be performed by a procedure with minimal nonspecific reaction, such as IgM-capture EIA ${ }^{2,5,25}$. The algorithm for serodiagnosis of toxoplasmosis in the USA includes an IgM measurement when time of infection needs to be defined. If IgM is positive at elevated indexes, infection has probably occurred in the prior three to six months. If it is positive at low indexes it may be a false-positive, be related to infection acquired in the prior two years or be related to reinfection. If it is negative, infection has occurred more than two years before. In individuals presenting with low IgM indexes, it was suggested by the authors that a second sample be collected, with both processed together to safely detect an increase of antibody levels ${ }^{25}$. In pregnant women with $\operatorname{low} \operatorname{IgM}$ indexes, it is difficult to determine the time of infection and exclude the possibility of transmission.

In 1989, HEDMAN et al. ${ }^{9}$ introduced the IgG-avidity test to help

(1) Immunology Section at Hospital Materno-Infantil Presidente Vargas, Porto Alegre, RS, Brazil.

(2) Department of Microbiology and Parasitology at Fundação Faculdade Federal de Ciências Médicas de Porto Alegre, Porto Alegre, RS, Brazil.

(3) Graduate Program in Clinical Pathology at Fundação Federal de Ciências Médicas de Porto Alegre, Porto Alegre, RS, Brazil.

Correspondence to: Myrian Morussi Reis, Rua Hilário Ribeiro 15/202, Bairro Moinhos de Vento, 90510-040 Porto Alegre, Rio Grande do Sul, Brazil. 


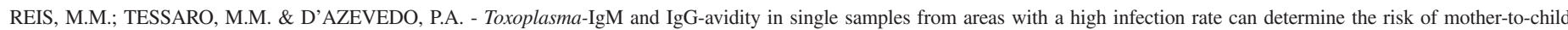
transmission. Rev. Inst. Med. trop. S. Paulo, 48(2):93-98, 2006.

diagnose acute infection based on the binding strength of specific IgG to a multivalent antigen of the parasite, which is produced at low concentrations after primary infection and increases over time. High avidity at the beginning of pregnancy has been used as a parameter to exclude post-conception infection ${ }^{9,10}$.

The risk of acute infection, parasitemia and mother-to-child transmission has been associated with high levels of $\mathrm{IgG}^{14}$, presence of $\operatorname{IgM}^{14}$ or IgM at high levels ${ }^{2,14,25}$ and low IgG-avidity $5,9,11,13,18,22,23$. Serological responses, however, follow diverse, individual rhythms. Low avidity, as well as the presence of $\operatorname{IgM}$ can be detected long after primary infection in some individuals. High and even very high IgG is not always observed in acute infection, especially during the first weeks ${ }^{11}$.

At Hospital Materno-Infantil Presidente Vargas in Porto Alegre, serology for toxoplasmosis is requested at the first prenatal visit, but the follow-up of susceptible pregnant women is poorly conducted or is not done at all. Samples from positive $\operatorname{IgG}$ and $\operatorname{IgM}$ pregnant women, who start prenatal care late or are serologically tested only at the time of labor, are commonly seen. It would be of value if the patients' immune status could be obtained of these single samples, bearing in mind that ultrasonography, amniocentesis and PCR (polymerase chain reaction) are requested based on it.

The aim of this study was, therefore, to evaluate IgG-avidity in samples from IgG- and IgM-positive pregnant women in relation to its capacity to identify the risk of mother-to-child transmission of Toxoplasma from single samples, requested at any time during pregnancy, considering the limitations of conventional serology. Specific IgG levels and specific IgM and IgG-avidity indexes were analyzed, and neonatal IgM was used as the serologic marker of motherto-child transmission.

\section{PATIENTS AND METHODS}

Anti-T. gondii IgG-avidity was prospectively determined in all positive IgG and IgM samples obtained from pregnant women at their first prenatal visit to Hospital Materno-Infantil Presidente Vargas in Porto Alegre, Rio Grande do Sul, Brazil, between 2000 and 2004, regardless of gestational age. Fifty-one mothers gave birth at the hospital. A newborn blood sample was drawn to process specific IgG and IgM.

IgG anti- T. gondii was performed using the MEIA, AxSYM ${ }^{\circledR}$ SYSTEM Toxo IgG commercial kit (Abbott Laboratories, Chicago, IL, USA). Results were expressed as International Units per milliliter (IU/mL), negative: $<2.0$, positive: $>3.0$, inconclusive: between 2.0 and 3.0.

IgM anti- $T$. gondii was performed using the ELFA, VIDAS TOXO IgM, TXM commercial kit (bioMérieux SA, Lyon, France). The results were expressed as indexes, negative: $<0.55$, positive: $>0.65$, inconclusive: between 0.55 and 0.65 .

VIDAS AVIDITY was also performed using the ELFA commercial kit and the results were expressed as indexes, low: $<0.2$, high: $>0.3$, inconclusive: between 0.2 and 0.3 .
Newborn specific $\operatorname{IgG}$ and $\operatorname{IgM}$ were processed with the same techniques.

Fisher's Exact test was used to analyze (a) the association between categorized IgM and transmission, (b) categorized $\operatorname{IgM}$ and categorized avidity and (c) categorized avidity and transmission. The Student $t$ test was used to analyze the association between avidity index and transmission. The Pearson correlation was used to analyze the correlation between IgM and avidity indexes.

The project was approved by the Ethics Committee of the Hospital Materno-Infantil Presidente Vargas.

\section{RESULTS}

IgG-avidity was performed on 168 samples from positive $\mathrm{IgG}$ and IgM pregnant women (about $2.5 \%$ of the total number of serologies performed during this period) and was high in $128(76 \%)$ and low or inconclusive in 40 (24\%). The gestational age was known in 105 women $(62.5 \%)$ of which $33(31.4 \%)$ were in the first, $36(34.3 \%)$ in the second and $36(34.3 \%)$ in the third trimester of gestation. Fifty-one mothers $(30 \%)$ gave birth at the hospital, thus making it possible to obtain neonatal $\operatorname{IgM}$.

Among the 128 pregnant women with high avidity, 32 gave birth at the hospital. IgG levels ranged from 58 to $8,832 \mathrm{IU} / \mathrm{mL}$ and $\mathrm{IgM}$ indexes ranged between 0.65 and 2.4. Eighteen mothers had low IgM indexes (between 1.0 and 3.0) and 14 only very low amounts of IgM (between 0.65 and 0.9). Eleven mothers were in the first, seven in the second and 14 the third trimester of gestation. Neonatal IgM tests were negative in all newborns.

Among the 40 pregnant women with low or inconclusive avidity, 19 gave birth at the institution (Table 1). IgG levels ranged from 106 to $3,356 \mathrm{IU} / \mathrm{mL}$ and $\mathrm{IgM}$ indexes from 0.65 to 11.9 . Six mothers had IgM indexes higher than 3.5 and avidity very low (M1 to M6), 11 had low $\operatorname{IgM}$ indexes (between 1.0 and 3.0) and two only traces of $\operatorname{IgM}$ (between 0.65 and 0.9 ). Two mothers were in the first, six were in the second and 11 were in the third trimester of gestation.

Five positive IgM newborns (M1, M2, M5, M11 and M13) and one stillbirth (M12) resulted from these mothers. In three infected newborns (M1, M2 and M5), the maternal IgM indexes were extremely high and in two infected newborns (M11 and M13) and the stillbirth (M12) these indexes were low. Maternal serologies of M2 and M5 were very similar: low levels of $\operatorname{IgG}$ and high indexes of $\operatorname{IgM}$.

According to the Fisher's Exact test, there is a statistically significant association between categorized IgM of mothers (index higher than 3.0) and transmission ( $<<0.028)$, neonatal IgM being the serologic marker of transmission. High $\operatorname{IgM}$ is predicted to result in a higher number of infected children than low or inconclusive IgM. There is also a statistically significant association between categorized IgM and categorized avidity $(\mathrm{p}<0.001)$, high IgM being associated with low avidity and vice-versa. There is also an association between categorized avidity and transmission $(\mathrm{p}<0.001)$, low avidity associated with transmission and high avidity associated with lack of transmission using the manufacturer threshold of 0.2. Reducing the threshold to 


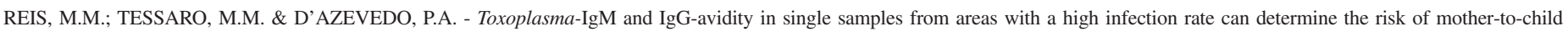
transmission. Rev. Inst. Med. trop. S. Paulo, 48(2):93-98, 2006.

Table 1

Mothers with positive or inconclusive IgM and low or inconclusive avidity, according to gestational age and neonatal IgM

\begin{tabular}{|c|c|c|c|c|c|c|}
\hline \multirow[t]{2}{*}{ Mother } & \multirow{2}{*}{$\begin{array}{l}\text { Gestational } \\
\text { age-trimester }\end{array}$} & \multicolumn{2}{|c|}{ IgG IU/mL } & \multirow{2}{*}{$\begin{array}{c}\operatorname{IgM} \\
\text { indexes }\end{array}$} & \multirow{2}{*}{$\begin{array}{l}\text { Avidity } \\
\text { indexes }\end{array}$} & \multirow{2}{*}{$\begin{array}{c}\text { Neonate } \operatorname{IgM} \\
\text { indexes }\end{array}$} \\
\hline & & ELFA & MEIA & & & \\
\hline M1 & $3 \mathrm{rd}$ & 3356 & $>300$ & 11.9 & 0.05 & positive (7.9) \\
\hline M2 & $3 \mathrm{rd}$ & 112 & 173 & 6.7 & 0.04 & positive (6.5) \\
\hline M3 & $1 \mathrm{st}$ & 2656 & $>300$ & 6.3 & 0.16 & negative \\
\hline M4 & $1 \mathrm{st}$ & 1060 & $>300$ & 4.6 & 0.04 & negative \\
\hline M5 & $3 r d$ & 155 & $>300$ & 4.5 & 0.04 & positive (9.3) \\
\hline M6 & $3 \mathrm{rd}$ & 748 & $>300$ & 4.1 & 0.08 & negative \\
\hline M7 & $3 r d$ & 560 & $>300$ & 3.0 & 0.08 & negative \\
\hline M8 & 2nd & 176 & 100 & 2.6 & 0.09 & negative \\
\hline M9 & $3 \mathrm{rd}$ & 352 & $>300$ & 2.5 & 0.15 & negative \\
\hline M10 & $3 \mathrm{rd}$ & 360 & $>300$ & 2.5 & 0.22 & negative \\
\hline M11 & 2nd & 244 & $>300$ & 2.4 & 0.13 & positive (1.4) \\
\hline M12 & $3 \mathrm{rd}$ & 2000 & $>300$ & 1.9 & 0.07 & stillbirth \\
\hline M13 & $3 \mathrm{rd}$ & 212 & 165 & 1.8 & 0.02 & positive (2.9) \\
\hline M14 & 2nd & 148 & 79 & 1.8 & 0.29 & negative \\
\hline M15 & 2nd & 280 & 277 & 1.7 & 0.08 & negative \\
\hline M16 & 2nd & 820 & $>300$ & 1.0 & 0.17 & negative \\
\hline M17 & 2nd & 460 & $>300$ & 1.0 & 0.19 & negative \\
\hline M18 & $3 \mathrm{rd}$ & 1416 & $>300$ & 0.7 & 0.18 & negative \\
\hline M19 & $3 \mathrm{rd}$ & 106 & 28 & 0.6 & 0.28 & negative \\
\hline
\end{tabular}

0.15 increases the association between low avidity and transmission. According to the Student $t$ test, there is an association between the avidity index and transmission $(\mathrm{p}<0.001)$, with a lower avidity index associated with a higher chance of transmission.

According to the Pearson correlation, there is a significant correlation between IgM and avidity indexes, moderately and inversely. Thus, a high avidity index corresponds to a low IgM index and viceversa $(r=-0.548, p<0.001)$. The relationship between $\operatorname{IgM}$ and avidity indexes when avidity is low, is shown in Fig. $1(\mathrm{r}=-0.472$; $\mathrm{p}=0.041)$, and when it is high, in Fig. 2 ( $r=-0.275 ; \mathrm{p}=0.128)$.

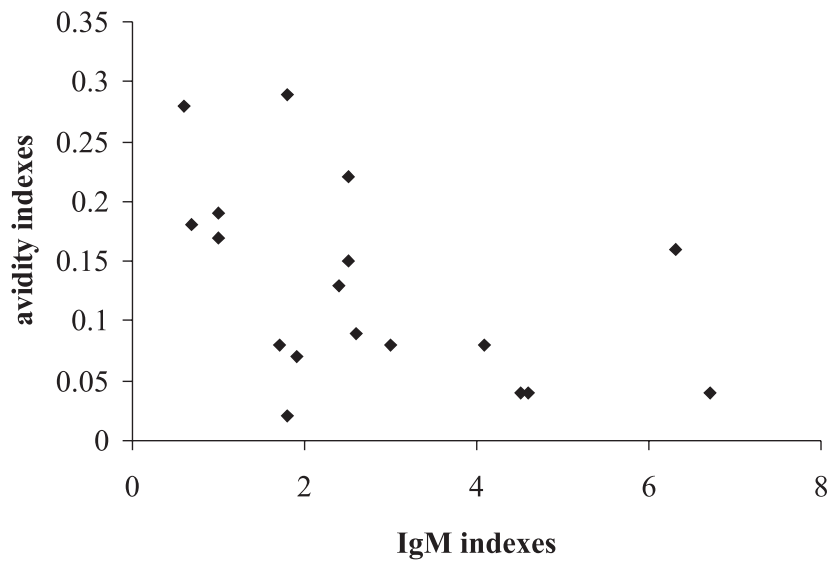

Fig. 1 - The moderate and inverse correlation between $\operatorname{IgM}$ and avidity indexes obtained in the samples with low avidity $(\mathrm{r}=-0.472, \mathrm{p}=0.041)$.

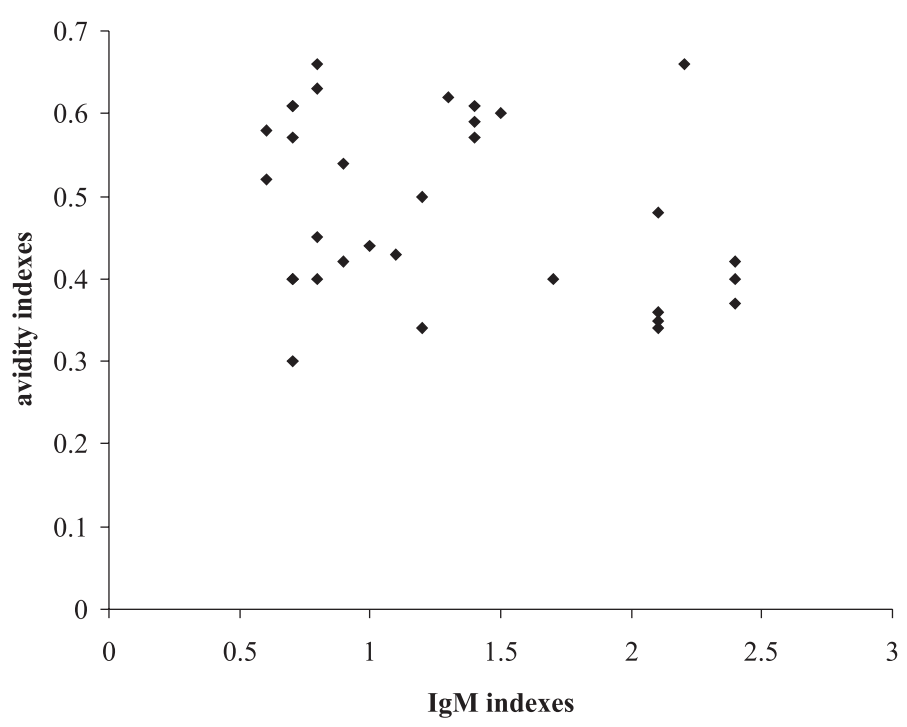

Fig. 2 - The non-significant correlation between IgM and avidity indexes, obtained in samples with high avidity. $(\mathrm{r}=-0.275, \mathrm{p}=0.128)$.

\section{DISCUSSION}

When routine testing for Toxoplasma antibodies is performed in pregnant women, the first serum sample is usually taken at the first antenatal health care visit confirming pregnancy, usually between eight and twelve weeks. At Hospital Materno-Infantil Presidente Vargas, the first serum sample from a pregnant woman is frequently obtained later, after 20 weeks of pregnancy, or even as a parturient. If the presence of 


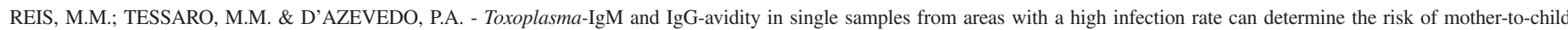
transmission. Rev. Inst. Med. trop. S. Paulo, 48(2):93-98, 2006.

IgM antibodies in single samples is the parameter used to identify acute infection, many women will be falsely identified as probably or possibly infected, according to the classification system produced by the working group of the European Research Network on Congenital Toxoplasmosis ${ }^{14}$, and they will undergo unnecessary diagnostic amniocentesis and/or antiparasitic treatment.

For these reasons, positive $\operatorname{IgG}$ and $\operatorname{IgM}$ in single samples were analyzed with regard to three parameters, IgG in IU/mL by MEIA and ELFA and IgM and IgG-avidity indexes by ELFA. The parameters were compared to neonatal infection determined by neonatal IgM, in order to assess the risk of mother-to-child transmission. The absence of neonatal $\operatorname{IgM}$ in the 32 infants born to mothers with high avidity, low indexes of $\operatorname{IgM}$ and even very high levels of $\operatorname{IgG}$ reinforces the importance of high avidity in evaluating the risk of transmission in any gestational age.

The presence of neonatal IgM in five infants born to mothers with low avidity and one stillbirth reinforces the importance of low avidity concerning the risk of transmission when it is measured in IgM-positive pregnant women. High indexes of $\operatorname{IgM}$ (M1, M2 and M5) also support the importance of IgM levels concerning the risk of transmission. M3 and M4 were under 20 weeks and their neonates were $\operatorname{IgM}$ negative, probably because the risk of transmission is lower in the first half of pregnancy.

The VIDAS avidity test has been standardized and optimized to exclude recent seroconversion in pregnant women presenting with elevated anti-Toxoplasma IgM levels in the first trimester of pregnancy ${ }^{6}$. The association between categorized avidity and transmission $(\mathrm{p}<$ 0.001 ) using the manufacturer recommended threshold of 0.2 is increased when reducing the threshold from 0.2 to 0.15 , with six cases of fetal transmission resulting from 12 mothers.

Without measuring avidity, the infected infants born to M11 and M13 with low levels of $\operatorname{IgG}$ and low indexes of $\operatorname{IgM}$ would not have been detected during pregnancy. In one infected newborn (M13), the only maternal parameter that strongly suggested fetal risk was IgGavidity. These are the results from conventional serologies, most difficult to correlate with the risk of transmission, as IgM can be residual in a descending curve.

The moderate and inverse correlation between $\operatorname{IgM}$ and avidity indexes obtained in the samples with low avidity (Fig. 1) in this series $(\mathrm{r}=-0.472, \mathrm{p}=0.041)$ is very similar to the correlation found by JENUM et al. ${ }^{11}$ between avidity indexes and estimated the time of infection $(r=0.46)$. The correlation between $\operatorname{IgM}$ and avidity indexes obtained in the samples with high avidity (Fig. 2) in this series ( $\mathrm{r}=-0.275, \mathrm{p}=0.128)$ is non-significant, meaning that high avidity did not show any relationship with $\operatorname{IgM}$. There was a better association of transmission with avidity $(\mathrm{p}<0.001)$ than with categorized IgM, index higher than $3.0(\mathrm{p}<0.028)$.

The dynamics of antibody formation must be remembered in interpreting the maternal results, especially in single samples. Considering the screening techniques used at Hospital Materno-Infantil Presidente Vargas, the sensitivity of MEIA- $\operatorname{IgG}^{3}$ and the capture design of ELFA-IgM ${ }^{2}$, the risk of mother-to-child transmission is related to the time of antibody appearance: $\left(1^{\text {st }}\right) \operatorname{IgM}>3.0 / \operatorname{IgG}<20 \mathrm{UI} / \mathrm{mL}$, $\left(2^{\text {nd }}\right) \operatorname{IgM}>3.0 / \mathrm{IgG}$ between 20 and $300 \mathrm{UI} / \mathrm{mL},\left(3^{\mathrm{rd}}\right) \operatorname{IgM}>3.0 / \mathrm{IgG}$ $>300 \mathrm{UI} / \mathrm{mL},\left(4^{\text {th }}\right) \operatorname{IgM}<3.0 / \mathrm{IgG}$ positive at any level. The last group, therefore, benefit most from obtaining the result of avidity, with low avidity indicating a higher risk, high avidity indicating a lower risk of transmission.

In JENUM et al. ${ }^{11}$ series, high IgG-avidity (above 20\%), can be used to exclude recent acute infection in the first 20 weeks, which reinforces the findings by LAPPALAINEN et al. ${ }^{13}$ who found a positive predictive value of $100 \%$ for high avidity in the five preceeding months.

In FLORI et al. series $^{6}$, the increase of avidity indexes was low; the average time to reach the threshold of 0.3 was 14.2 months. No women reach this threshold either at four months or at six months after seroconversion. According to the authors, it is justifiable to decrease the threshold for exclusion of a recent infection of less than four months to 0.2 and use the company threshold of 0.3 for exclusion of infections which have occurred more than six months ago. The kinetics of the avidity test in five groups of women based on the type and duration of treatment given has also been evaluated and there was no significant difference when comparisons were made between the groups.

The best approach to prevent and control congenital toxoplasmosis is not clear. In France, a country with a high prevalence of infection, prevention is performed through serological screening and follow-up of susceptible mothers until childbirth with monthly serology ${ }^{1,16,21}$. Seroconversion indicates maternal acute infection. Parasite detection in amniotic fluid can be performed by in vitro culture, mouse inoculation and PCR to confirm fetal infection.

PCR for detection of $T$. gondii has revolutionized prenatal diagnosis by enabling an early diagnosis to be made, thereby avoiding the use of more invasive procedures on the fetus, thanks to its sensitivity, specificity and rapidity ${ }^{7,17}$. However, the results of a European collaborative study highlighted the lack of homogeneity between PCR protocols and performance and underlined the need for an external quality assurance scheme ${ }^{19}$. There are, also, marked differences in PCR sensitivity depending on gestational age at the time of the amniocentesis. Furthermore, PCR on amniotic fluid is not recommended for HIV-infected women, because of the risk of transmitting the HIV virus to the fetus during the procedure ${ }^{17}$.

DUNN et al. ${ }^{4}$ analyzed the status of congenital infection in 554 cases. The overall maternal-fetal transmission rate was $29 \%$, which masked a sharp increase in risk from $6 \%$ at 13 weeks to $72 \%$ at 36 weeks. Women who seroconverted at 24-30 weeks carried the highest risk $(10 \%)$ of having a congenitally infected child with early clinical signs and at risk of long-term complications.

Most infected newborn babies do not have overt signs of disease at birth but are at substantial risk of developing long-term sequelae: chorioretinal disease in up to $85 \%$ of infected children and neurological abnormalities. Marked reductions in frequency and severity of disease at birth have been associated with in utero treatment. Significant reductions in expected long-term complications have been associated with extended post-natal treatment regimens started in the newborn period or as a continuation of in utero treatment ${ }^{1,16,21}$. 
Despite the use of advanced methods, some cases of congenital toxoplasmosis cannot be detected early, which underlines the importance of careful follow-up of newborns at risk ${ }^{21}$. In Denmark, a country with a low prevalence of infection, a neonatal screening programme based solely on detection of Toxoplasma-specific IgM antibodies evaluated from the PKU card could identify more than $75 \%$ of infected infants born to untreated mothers ${ }^{15}$. This strategy could be the most appropriate one for countries with a low prevalence of infection ${ }^{8,15}$. In the United States, an isolated serum sample, often obtained either late in the first trimester or during the second or third trimester, is the only source of information on whether the fetus is at risk $^{26}$.

RICCI et al. ${ }^{20}$ compared the results of the two approaches in a population with a high infection rate in order to evaluate the effectiveness of these strategies in 5,288 susceptible pregnancies, 188 identified as infected, and 9,730 neonates. In this series, neonatal screening for toxoplasmosis seems to be less effective than pregnancy screening. In a study from Porto Alegre, neonatal screening identified cases of congenital toxoplasmosis acquired and transmitted in late pregnancy and undetected by prenatal screening ${ }^{12}$.

There is a high prevalence of congenital toxoplasmosis in Porto Alegre $^{12}$. Prevention programs using single samples should be approached carefully. It is necessary to choose the best combination of assays ${ }^{11,22}$. Because the IgG-avidity test is largely employed as a $2^{\text {nd }}$ level test, 117 cases of toxoplasmosis in pregnancy divided into the risk categories according to Lebech's criteria were re-examined including avidity that could define 77 out of $117(65.8 \%)$ with only a single serum sample. The avidity test proved to be a useful method to classify the Toxoplasma infection in a single serum sample, especially during pregnancy ${ }^{23}$.

A large European multicenter study ${ }^{22}$ explored the diagnostic performances of 20 antibody assays and their combinations in assessing the time of primary infection with $T$. gondii. The sample criteria permitted evaluation of test performance in terms of clinical sensitivity and specificity rather than analytical sensitivity and specificity. Excellent diagnostic performances, specificity near 99\% maintaining sensitivities of $95 \%$ or higher, were reached by sequential use of highly sensitive IgM assays and methods that explored IgG quality, differential agglutination and avidity assays. The prerequisite for IgG seropositivity may have ruled out samples in the first two weeks of infection, when not all the antibody isotypes have yet been expressed.

For Brazilian public health institutions, the best serological model to prevent congenital toxoplasmosis using single samples would be analyzing for IgG and IgM antibodies using sensitive methods. Avidity should be done in all positive $\operatorname{IgM}$ serologies. High avidity helps to exclude acute infection in the last 20 weeks. Low avidity is associated with risk of transmission which increases during gestation; therefore, neonatal IgM should be performed in all low IgG-avidity maternal serologies. Negative neonates, even asymptomatics, should be carefully followed-up during the first year to exclude congenital toxoplasmosis.

\section{CONCLUSIONS}

From these results it can be concluded that IgG-avidity performed in single samples from positive anti-Toxoplasma IgM pregnant women can determine the risk of transmission at any time during pregnancy, especially if the indexes of the two tests are analysed compared to gestational age. This model may be less expensive in developing countries with a high infection rate than the follow-up of susceptible mothers until childbirth with monthly serology, and it creates a new perspective for the diagnosis of congenital toxoplasmosis.

\section{RESUMO}

\section{Avidez de IgM e IgG de Toxoplasma em amostras de áreas com alta taxa de infecção pode determinar risco de transmissão materno-fetal}

A avidez de IgG anti-Toxoplasma foi realizada em 168 amostras IgG e IgM positivas de gestantes, coletadas em qualquer período da gestação, para avaliar o valor preditivo do risco de transmissão maternofetal em amostra única, considerando as limitações da sorologia convencional. A IgM neonatal foi considerada o marcador sorológico de transmissão. Testes fluorométricos foram realizados para $\mathrm{IgG}, \mathrm{IgM}$ (imunocaptura) e avidez de IgG. Cinqüenta e uma das 128 gestantes testadas tiveram os partos realizados na instituição e a IgM neonatal foi obtida. Os resultados mostraram $32(62.75 \%)$ gestantes com avidez alta, índices de $\operatorname{IgM}$ entre 0,6 e 2,4 e nenhum recém-nascido infectado. Dezenove $(37.25 \%)$ tiveram avidez baixa ou inconclusiva, índices de IgM entre 0,6 e 11,9, cinco recém-nascidos infectados e um natimorto. Em dois recém-nascidos infectados e no natimorto, os índices maternos de IgM foram baixos e em um recém-nascido infectado, o único parâmetro materno que sugeriu risco para o feto foi a avidez de IgG. No presente estudo, a avidez de IgG realizada em amostras isoladas de gestantes IgM positivas auxiliou a determinar o risco de transmissão durante toda a gestação, especialmente quando os índices dos dois testes foram analisados em relação à idade gestacional. Este modelo pode ser menos oneroso para países em desenvolvimento com alta prevalência da infecção e cria nova perspectiva para o diagnóstico da toxoplasmose congênita.

\section{REFERENCES}

1. BESSIÈRES, M.H.; BERREBI, A.; ROLLAND, M. et al. - Neonatal screening for toxoplasmosis in a cohort of 165 women infected during pregnancy and influence of in utero treatment on the results of neonatal tests. Europ. J. Obst. Gynecol. reprod. Biol., 94: 37-45, 2001.

2. CAMARGO, M.E. - Toxoplasmose. In: FERREIRA, A.W. \& ÁVILA, S.L.M., ed. Diagnóstico laboratorial das principais doenças infecciosas e auto-imunes. Rio de Janeiro, Guanabara-Koogan, 2001. p. 278-288.

3. CIMON, B.; MARTY, P.; MORIN, O. et al. - Specificity of low anti-Toxoplasma IgG titers with IMx and AxSYM Toxo IgG assays. Diagn. Microbiol. infect. Dis., 32: 65-67, 1998.

4. DUNN, D.; WALLON, M.; PEYRON, F. et al. - Mother-to-child transmission of toxoplasmosis: risk estimates for clinical counseling. Lancet, 353: 1829-1833, 1999.

5. FERREIRA, A. W. \& CAMARGO, M.E. - Toxoplasmosis and the laboratory: diagnosis and a constant striving for improvement. Rev. Inst. Med trop. S. Paulo, 44: 119$120,2002$.

6. FLORI, P.; TARDY, L.; PATURAL, H. et al. - Reliability of immunoglobulin G antitoxoplasma avidity test and effects of treatment on avidity indexes of infants and pregnant women. Clin. Diagn. Lab. Immunol., 11: 669-674, 2004. 


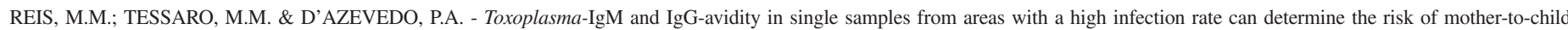
transmission. Rev. Inst. Med. trop. S. Paulo, 48(2):93-98, 2006.

7. FORESTIER, F.; HOHLFELD, P.; SOLE, Y. \& DAFFOS, F. - Prenatal diagnosis of congenital toxoplasmosis by PCR: extended experience. Prenat. Diagn., 18: $407-$ 419, 1998.

8. GUERINA, N.G.; HSU, H.-W.; MEISSNER, H.C. et al. - Neonatal serologic screening and early treatment for congenital Toxoplasma gondii infection. New England Regional Toxoplasma Working Group. New Engl. J. Med., 330: 1858-1863, 1994.

9. HEDMAN, K.; LAPPALAINEN, M.; SEPPÄLÄ, I. et al. - Recent primary Toxoplasma infection indicated by a low avidity of specific IgG. J. infect. Dis., 159: 736-740, 1989.

10. HOLLIMAN, R.E.; RAYMOND, R.; RENTON, N. et al. - The diagnosis of toxoplasmosis using IgG avidity. Epidem. Infect., 112: 399-408, 1994.

11. JENUM, P.A.; STRAY-PEDERSEN, B. \& GUNDERSEN, A.G. - Improved diagnosis of primary Toxoplasma gondii infection in early pregnancy by determination of antiToxoplasma immunoglobulin G avidity. J. clin. Microbiol., 35: 1972-1977, 1997.

12. LAGO, E.G.; NETO, E.C.; MELAMED, J. et al. - Neonatal screening for congenital toxoplasmosis in Porto Alegre, RS, Brazil. In: INTERNATIONAL CONFERENCE ON TOXOPLASMOSIS, Copenhagen, 2003. Proceedings. Copenhagen, The Panum Institute; University of Copenhagen, 2003.

13. LAPPALAINEN, M.; KOSKELA, P.; KOSKINIEMI, M. et al. - Toxoplasmosis acquired during pregnancy: improved serodiagnosis based on avidity of IgG. J. infect. Dis., 167: 691-697, 1993.

14. LEBECH, M.; JOYNSON, D.H.; SEITZ, M. et al. - Classification and case definitions of T. gondii infection in immunocompetent pregnant women and their congenitally infected offspring. Europ. J. clin. Microbiol. infect. Dis., 15: 799-805, 1996.

15. LEBECH, M.; ANDERSEN, O.; CHRISTENSEN, N.C. et al. - Feasibility of neonatal screening for toxoplasmosis infection in the absence of prenatal treatment. Danish Congenital Toxoplasmosis Study Group. Lancet, 353: 1834-1837, 1999.

16. LYNFIELD, R.; HSU, H.W. \& GUERINA, N.G. - Screening methods for Toxoplasma and risk of disease. Lancet, 353: 1899-1900, 1999.
17. MONTOYA, J.G. - Laboratory diagnosis of Toxoplasma gondii infection and toxoplasmosis. J. infect Dis., 185 (suppl.1): S73-S82, 2002.

18. MONTOYA, J.G.; LIESENFELD, O.; KINNEY, S.; PRESS, C. \& REMINGTON, J.S. VIDAS test for avidity of Toxoplasma-specific immunoglobulin $\mathrm{G}$ for confirmatory testing of pregnant women. J. clin. Microbiol., 40: 2504-2508, 2002.

19. PELLOUX, H.; GUY, E.; ANGELICI, M.C. et al. - A second European collaborative study on polymerase chain reaction for Toxoplasma gondii, involving 15 teams. FEMS Microbiol. Lett., 165: 231-237, 1998.

20. RICCI, M.; PENTIMALLI, H.; THALLER, R.; RAVA, K. \& DI CIOMMO, V. - Screening and prevention of congenital toxoplasmosis: an effectiveness study in a population with a high infection rate. J. maternal-fetal neonat. Med., 14: 398-403, 2003.

21. ROBERT-GANGNEUX, F.; GAVINET, M.-F.; ANCELLE, T. et al. - Value of prenata diagnosis and early postnatal diagnosis of congenital toxoplasmosis: retrospective study of 110 cases. J. clin. Microbiol., 37: 2893-2898, 1999.

22. ROBERTS, A.; HEDMAN, K.; LUYASU, V. et al. - Multicenter evaluation of strategies for serodiagnosis of primary infection with Toxoplasma gondii. Europ. J. clin. Microbiol. infect. Dis., 20: 467-474, 2001

23. ZOTTI, C.; CHARRIER, L.; GIACOMUZZI, M. et al. - Use of avidity test in case definition of toxoplasmosis in pregnancy. New Microbiol., 27: 17-20, 2004.

24. WALlON, M.; LIOU, C.; GARNER, P. \& PEYRON, F. - Congenital toxoplasmosis: systematic review of evidence of efficacy of treatment in pregnancy. Brit. med. J., 318: $1511-1514,1999$.

25. WILSON, M.; SCHANTZ, P.M. \& TSANG, V.C.W. - Clinical Immunoparasitology. In ROSE, N.R.; MACARIO, E.C.; FOLDS, J.D.; CLIFFORD LANE, H. \& NAKAMURA, R.M., ed. Manual of clinical laboratory Immunology. Washington, American Society for Microbiology, 1997. p. 575-584.

26. WONG, S.Y. \& REMINGTON, J.S. -Toxoplasmosis in pregnancy. Clin. infect. Dis., 18: 853-861, 1994.

Received: 19 April 2005

Accepted: 19 December 2005 